УДК $821.161 .1,82-34$

DOI: $10.17223 / 19986645 / 56 / 13$

\title{
Л.А. Курышева
}

\section{О ПЕРВОМ РУССКОМ ПЕРЕВОДЕ СКАЗКИ М. ЛЕПРЕНС ДЕ БОМОН «КРАСАВИЦА И ЗВЕРЬ»}

\begin{abstract}
Реконструированы обстоятельства первого перевода на русский язык сказки Лепренс де Бомон «Красавица и зверь» (1756) и дана характеристика его особенностей. Материалом послужил перевод Х. Г. Демидовой - «Повесть о Лебеле и звере» (1758), перевод П.С. Свистунова (1761), дневники братьев Демидовых. Поставленные задачи решены при помощи реконструкиии биографического контекста, анализа языковых и экстралингвистических особенностей. Для языка перевода характерно точное следование оригиналу, вплоть до синтаксических калек. В то же время его яркой чертой является употребление просторечных выражений, введение русских реалий. Публикация рукописного перевода (ОРКР НЗБ СГУ, № 456) осуществляется впервые.

Ключевые слова: рукописная повесть XVIII в., Демидовы, Лепренс де Бомон, «Красавица и чудовище», АТ 425 С.
\end{abstract}

В 1756 г. в Лондоне вышло примечательное издание, которое на протяжении всего XVIII в. пользовалось большой популярностью в качестве учебного пособия для молодых девушек в пансионах и домашнем образовании; оно стало первым в ряду подобных книг. Франкоязычный учебник М. Лепренс де Бомон «Magasin des enfants» [1] содержал поучительные разговоры, начальные сведения по географии, истории, выдержки из Святого Писания и нравоучительные сказки ${ }^{2}$; в числе последних - сказка о

\footnotetext{
${ }^{1}$ Статья подготовлена в рамках поддержанного РФФИ научного проекта № 16-0400214-ОГН.

${ }^{2}$ Мари Лепренс де Бомон (1711-1780) много лет провела в Англии в качестве гувернантки, там же ею были созданы первые учебные пособия для детей и юношества; в качестве нравоучительно-развлекательного материала в них вошли краткие пересказы сказочных эпизодов из известных произведений и оригинальные сказки [2]. В России большой вклад в детскую литературу был сделан А.Т. Болотовым, его первый в этом отношении опыт - «Детская философия, или Нравоучительные разговоры между одною госпожою и ее детьми...» - был написан под влиянием сочинения Лепренс де Бомон: [3. С. 243-246; 4. С. 116]. Обзор популярных в России XVIII в. книг для детей и юношества представлен в монографии М.А. Костюхиной [5. С. 9-43]. Возникновение детского направления в литературе автор относит к концу 70-х гг. XVIII в. К сожалению, исследовательница не касается влияния на формирование детской литературы, русской в частности, учебного пособия Лепренс де Бомон, считая его, по-видимому, вторичным по отношению к подобным изданиям, и ошибочно дает указание на позднее издание «Детского училища» в качестве первого русского издания. Впрочем, ошибки в датировке первых ориентированных на детей книг не помешали автору дать характеристику жанру «беседы», который был, по сути, изобретен Лепренс де Бомон [5. С. 18-20]. О популярности сочинений Лепренс де Бомон в России см.: [6. С. 17-18].
} 
красавице и звере, известность которой превзошла ее непосредственный источник, роман Г.-С. де Вильнёв «Histoire de la Belle et de la Bête» $(1740)^{1}$. Среди подписчиков лондонского издания было немало русских аристократических семей [10]. Русский перевод не замедлил себя ждать: он был выполнен П.С. Свистуновым, первый том «Детского училища» появился в печати в 1761 г. $^{2}$ Однако тремя годами ранее Хиония Демидова (17461792) $[11]^{3}$, дочь Григория Акинфиевича Демидова, сделала свой перевод сказки о красавице и звере и подарила его в виде рукописной книги «Повесть о Лабеле и звере» брату П.Г. Демидову.

По-видимому, Хиония Демидова получила «Magasin des enfants» в числе других книжных новинок, отправляемых регулярно старшими братьями из образовательного путешествии по Европе 1751-1761 гг. ${ }^{4}$ Возможно, что новость о выходе в свет оригинального учебного пособия, предназначенного для воспитания и обучения благородных девиц, братья почерпнули в своем «русском» заграничном кругу. В поездке Демидовы регулярно общались с представителями отечественной аристократии и близкими к двору дипломатами, в том числе русским посланником в Англии князем А.М. Голицыным, шведским послом в России бароном М. Поссе, сенатором бароном А.С. Строгановым, бароном К.Е. Сиверсом [15]. Все эти персоны были в числе русских подписчиков лондонского издания Лепренс де Бомон $^{5}$.

${ }^{1}$ Сопоставление романа Вильнёв и сказки Лепренс де Бомон представлено в работе [7]. См. также примечания в современном научном издании сказок Лепренс де Бомон: [8. С. 1493-1504].

${ }^{2}$ О переводчике П.С. Свистунове см.: [9]. О востребованности сочинения Лепренс де Бомон среди русских читателей говорят тиражи, переиздания и новые переводы. Завершая подсчет совокупного тиража русских изданий «Детского училища» с 1761 по 1800 г., который составил не менее 15000 экземпляров, Н.А. Копанев делает вывод, что «по этому показателю произведение Лепренс де Бомон... практически не имело себе равных в русском репертуаре книг для детского чтения XVIII века» [10. С. 4].

3 Выражаю сердечную благодарность сотруднику «Демидов-ценра» (г. Ревда) Е.В. Марченко за консультацию о семье Демидовых. О некоторых жизненных обстоятельствах Х.Г. Демидовой, вышедшей в 1764 г. замуж за русского дипломата А.С. Стахеева, см.: [12]. В русском фонде РНБ хранится «Санкт-Петербургский календарь на лето... 1763» (38.34.3.38) с собственноручными записями Демидовой, в настоящее время он находится в свободном электронном доступе (см.: [13]).

${ }^{4}$ Об интересе А.Г. Демидова и его сыновей к книжным новинкам см.: [14. С. 17, 33]. На основании содержания Журналов и писем братьев Демидовых Г.А. Победимова так описывает согласование с отцом приобретений: «Пересылка корреспонденции, и в особенности посылок, была делом хлопотным. Обычно сыновья сообщали отцу о чемто, что их заинтересовало (если сам он не распоряжался о покупке, как это было с сочинениями Вольтера), затем ждали ответа с разрешением купить или заказать, после чего начинались переговоры о приобретении. В один конец письмо шло больше 2 месяцев, что свидетельствовало о неторопливости жизни вообще. Проще всего было покупать и отправлять книги и ноты» [Там же. С. 23].

${ }^{5}$ Список петербургских подписчиков был помещен в конце четвертого тома издания. Он был опубликован Н.А. Копаневым, при этом исследователем была проделана 
Рукописная книга, созданная двенадцатилетней Хионией Демидовой и подарочно оформленная, посвящена «братцу» Петру Григорьевичу Демидову. Это посвящение могло быть обусловлено несколькими причинами. Во-первых, особенными взаимоотношениями между сестрой и младшим из трех братьев, более близким по возрасту (год рождения Петра - 1740) и в дальнем путешествии зачастую выступавшим в роли медиатора между братьями и семьей [14. С. 18]. Во-вторых, родители были чрезвычайно озабочены занятиями сыновей русским языком, который немало пострадал в заграничном путешествии при интенсивном овладении другими языками, особенно у младшего Петра [Там же. С. 12-14]. Отец семейства, Г.А. Демидов, или сама Хиония могли инициировать рукотворный подарок младшему сыну и брату как форму благодарности за присланную книгу и одновременно с той целью, чтобы он мог попрактиковаться в чтении на русском языке. ${ }^{1}$ Кроме того, детали сказки перекликались с жизненными обстоятельствами семьи Демидовых. Подобно сказочным героям «Красавицы и зверя» глава семейства - это человек дела, при этом добродетельный и патриархального склада, не жалеющий средств на воспитание и образование своих шестерых детей. Звучащие в сказке «ботаническая» и музыкальная темы тоже соответствовали семейным увлечениям Демидовых: Григорий Акинфиевич был страстным садоводом, он основал первый в России частный ботанический сад (под Соликамском) и состоял в переписке с Карлом Линнеем; все его дети обучались музыке, особенно любил музыкальные занятия Петр [14. С. 15, 17-18, 25, 27; 15].

Рассмотрим теперь особенности перевода Х.Г. Демидовой (далее Х. Д.). Для ее перевода в целом характерно точное следование оригиналу, вплоть до синтаксических калек. В то же время в нем встречаются разговорные выражения и произведена систематическая замена на русские реалии вроде «версты», «копейки», «девки» (в значении 'служанки').

Кратко остановимся на грамматических и смысловых ошибках, встречающихся в рукописном тексте. Их разграничение на случайные, сделанные, например, в ходе переписывания на чистовик, и системные позволяет нам судить о степени овладения молодой девушкой французским языком и русской грамматикой.

К ошибкам, сделанным вследствие невнимательности, можно отнести пропуски слов и омофонные подмены. Например, привезенный купцом от зверя сундук в переводе Х. Д. «наполнен золотыми платьями, бралиантами», в то время как во французском источнике бриллиантами украшены именно золотые платья («garnies de diamants»). Фразу о том, что Красавица с большой добротой разговаривала с бедняками («elle parlait aux pauvres gens avec tant de bonté»), Демидова переводит следующим образом: «рас-

работа по атрибуции подписчиков на основании зачастую искаженной транслитерации имен (см.: [10]).

${ }^{1} \mathrm{O}$ ежедневных занятиях русским языком, в том числе обязательном вечернем чтении, см.: [14. С. 14-15, 25-26]. 
суждала $о$ бедных людях с великою милостию» (здесь и далее в цитатах курсив мой. - Л.К.). По-видимому, мы имеем здесь смешение омофонных предлогов - русского o и французского аих. Наконец, восклицание «Allons!» вместо понуждения со значением «ну же!» Х. Д. переводит императивом «Пойдем!».

Систематическая ошибка, свидетельствующая о пока еще не освоенной стороне французской грамматики, была допущена при переводе конструкций, обозначающих близкое будущее и намерение что-либо сделать (aller faire qch), формой прошедшего времени. Например, «vous allez devenir une grande reine» - «вы сделались великою королевою». Трудность молодой переводчицы вызвала и синтаксическая конструкция, обозначающая одновременность действий: «à peine fut-elle dans son lit, qu'elle s'endormit» ('как только...') - «а потом легла и заснула».

Обратимся к синтаксическим калькам в переводе Х. Д. Во-первых, это касается употребления предлогов: купец и его дочь прибывают во дворец зверя «на вечер», что соответствует «sur le soir» оригинала; довольно часто встречается выражение «сказала сама $в$ себе» («dit à elle-même») наряду с выражением «сказала сама себе». Во-вторых, это калькирование французского глагольного управления. В качестве иллюстрации приведем выражения с глаголом отказывать / отказываться: отсутствует русская возвратная частица во фразе «ежели твои дочери откажут за тебя умереть» (cp. «si vos filles refusent de mourir pour vous»), нарушено глагольное управление в словах «откажешь сие веселие» (ср. «si vous me refusez ce plaisir»).

В переводе Х. Д. встречаются ошибки в русском падежном склонении. Например, в форме винительного падежа для одушевленного лица - сестры «пасут овцы». Особенно ярко это видно на примере склонения слова платье (во французском соответствует форме множественного числа habits) в родительном, винительном, творительном и предложном падежах: «нет у ней платья», «он привез им богатое платья», «взяла самое худое себе платья», «наполнен платьями», «ящык с платьям», «о прекрасном их платее». Ошибки в употреблении форм винительного и творительного падежа, возможно, говорят о том, что освоение русской письменной речи шло одновременно с занятиями французским языком и что русское письмо Х. Д. было, скорее, фонетическим, чем подкрепленным знанием грамматики. Нашу версию подтверждают другие случаи фонетического письма, например «шакалатной столик» и «напившис шоколату», спорадическая подмена $u$ на $\breve{u}$ («хозяйн» вместо «хозяин», форма настоящего времени 3 л. мн. ч. «думайте» вместо «думаете»), а также системное неразличение употребления мягкого и твердого знаков. В то же время часть этих явлений могла быть вызвана механическим переписыванием с черновика.

Неполное понимание французского текста приводит к ошибочной интерпретации и «достраиванию» смысла. В демидовском переводе Лабель сожалеет о том, что зверь некрасив: «Ах... сожалею, что он дурен, ах ежели б он был пригож!», в то время как в оригинале мысль героини сложнее. Красавица отмечает именно противоречие - при внешнем безобразии зверь 
имеет доброе сердце: «Hélas! ...c'est bien dommage qu'elle soit si laide, elle est si bonne!». Другой пример возьмем из начала сказки. Лепренс де Бомон, представляя свою героиню, говорит, что она красивее и вообще лучше своих сестер («Cette cadette qui était plus belle que ses soeurs, était aussi meilleure qu'elles»). В своем переводе Х. Д. уточняет, чем именно лучше, помимо красоты: «...была пригожее и разумнее ея сестер» ${ }^{1}$. Еще один пример неточного следования оригиналу встречаем в эпизоде, в котором фея превращает злых сестер в каменные статуи, сохраняя при этом их разум: «mais conservez tout votre raison sous la pierre». Это наказание должно продлиться до того момента, когда завистницы осознают свои ошибки. В переводе Х. Д. raison (разум, осознанность, способность размышлять) заменен понятием характера: «сохраняйте ваш нрав под камнем». Таким образом, в этом эпизоде проклятие волшебницы тематически связано с ее дальнейшим размышлением о том, что это был бы род чуда, если бы злое сердце (злой нрав) способно было исправиться.

Необъяснимо, почему в последнем предложении сказки Х. Д. ослабляет причинно-следственную связь: «...он женился на Беле, которая жила с ним долгое время в совершенном щастие, ибо которое основано было на добродетели», при этом слово ибо - соответствует рагсе quе оригинала - взято в прямые скобки как знак изъятия. Так же необъяснимо, почему при описании непогоды, застигнувшей купца в пути, Х. Д. упоминает только о сильном дожде, в то время как в оригинале речь идет о снеге («il neigeait horriblement»), чуть ниже в русском тексте говорится о том, что купец промок от дождя (в оригинале от дождя и снега - «la pluie et la neige l'avaient mouillé»). Ниже по тексту купец утром через окно «не видал ничего кроме цветников розовых» (в оригинале он не видит больше снега, но только цветники - «il... ne vit plus de neige, mais des berceaux de fleurs»).

Наконец, остановимся на одном примечательном пропуске, причины которого лежат в культурной неосведомленности юной переводчицы. Это маленькая колкость Лепренс де Бомон в отношении правил светской жизни. Как мы помним, зверь не имеет человеческого разума, в чем признается своей гостье. В ответ Красавица подбадривает его, возражая, что добродетель выше и красоты и ума. Описывая ежедневные встречи Красавицы со зверем, Лепренс де Бомон отмечает, что визави героини не присущ светский лоск: зверь разговаривает с Красавицей здраво, но никогда с тем, что принято называть в светском обществе остроумием («avec assez de bon sens, mais jamais avec ce qu' on appelle esprit dans le monde»). Этим она еще раз подчеркивает нравственные достоинства главного мужского персонажа - его чистосердечие и прямоту. В своем переводе X. Д. не замечает критического подтекста и ошибочно припи-

1 По пути усиления дидактики и переноса акцентов в этом фрагменте идет и П.С. Свистунов: «лутче не только лицем, но и сердцем» [16. С. 82]. 
сывает зверю некоторое тупоумие: «...зверь... разговаривал... нарочито хорошо, но не очень разумно» 1 .

Еще одна особенность демидовского перевода - это внесение русских реалий и употребление особенной лексики при описании семейных отношений и домашнего уклада. Обращает на себя внимание взаимное называние сказочных персонажей «батюшка», «сестрица», «братец», что, надо думать, отражает особенности бытовой речи и патриархальный стиль общения в семье Демидовых. Это подтверждают посвящение перевода «братцу» и стиль писем старших братьев Х. Д., посылаемых из-за границы, в которых домашние неизменно поименованы ласкательно [15]. Приведем примеры патриархальной по духу лексики, относящейся к русскому традиционному укладу: сестры «ходят как боярыни и пасут овцы» (ср.«faire les dames, en gardant les moutons») $)^{2}$. Вместо миль и французской мелкой монеты су в переводе Х. Д. расстояние меряется «верстами», а мелкая монета названа «копейкой». Большой класс лексики, описывающей жилище и его части, составляют как относительно новые слова, так и восходящие к допетровскому укладу. Так, во французском оригинале жилище зверя обозначено как дворец (palais) и замок (château). В отношении обоих слов Х. Д. пользуется словами «дворец» и «палаты»; равным образом употребляются их производные - «палатные двери» (la porte du palais) и «дворцовый сад» (jardin du palais). Кроме того, в переводе Х.Д. мы встречаем обозначение «большой дом» и «дом» для «grand palais» и «château». «Chambre» переведено и как «горница», и как «спальня», «grands appartements» - «горница», «salle» - «зала» ${ }^{3}$. Вернувшись домой, Красавица зовет «служанку» (servante), чуть ниже она обозначена как «девка», затем снова «служанка».

Как и в приведенных выше примерах, в отношении многих понятий Демидова равным образом подбирает русские аналоги и пользуется калькированием: la figure (лицо) Х. Д. переводит как «образина» и «фигура», «petite creature» (так называют Красавицу завистливые сестры) - «негодная тварь» и «малинкая креатура». Однако в целом при переводе с французского Х. Д. не идет по пути создания фразеологических калек, а подбирает соответствующие смыслу русские выражения. Например: «купец пал в ноги» (ср.«se jeta à genoux»), «я даю тебе четверть часа на покаяние» (ср. «је ne vous donne qu'un quart d'heure pour demander pardon à Dieu»), «меня оставьте с Богом» (ср. «m'abandonnerez au secours du Ciel») $)^{4}$.

1 Замечание о светских правилах обхождения было опущено и в переводе П.С. Свистунова: «...разговаривал с нею во время ужина с довольным разсуждением, однако не так, как бы он мог разсуждать имея здравой разум» [16. С. 107].

${ }^{2} \mathrm{Cp}$. в переводе П.С. Свистунова: «...почитают себя великими госпожами, гуляя за овечьим стадом» [Там же. С. 84].

${ }^{3}$ Во французском оригинале лошадь идет на конюшню и затем купец ее там привязывает, Х. Д. вносит уточнение, что купец привязывает лошадь к «яслям».

${ }^{4}$ Обратим внимание на перевод Демидовой глагола toucher со значением эмоционального воздействия: «Итак, не думай умилостивить меня твоим ласкательством» (ср. «ne croyez pas me toucher par vos flatteries»), «не было в свете столь милостивой как вы, 
При переводе французской сказки Х. Д. широко пользуется разговорными и даже просторечными выражениями. В то же время ее перевод содержит образцы светского речевого поведения. Приведем примеры того и другого.

Разговорные выражения: «жизнь мою почитаю ни за что» (cp. «је ne suis pas fort attachée à la vie»), «не болтай же мне больше» (cp. «ne me raisonnez pas»), «побожись возвратится сюда» (ср. «jurez que vous reviendrez»), «не противно ли вам будет» (cp. «voulez-vous bien que»), «Вы меня век не оставите» (ср. «ne me quittez jamais»), «привесть... в сердце» (ср. «exiter la colère»), «зжалилась о бедном звере» (сp. «sentit un grande compassion»), ревность «еще пуще умножалась» (ср. «augmenter beaucoup»), «чтобы... досыти наплакаться» (ср. «tout à leur aise»), «не пригоже ли мы еe» (cp. «plus aimable»), «я что-то вздумала» (cp. «vient une pensée»).

Формулы вежливости: Лабель отказывает соискателям ее руки «честным образом тем благодаря» (ср. «remercia bien honnêtement»), «вы изволите памятовать» (cp. «d'avoir eu la bonté de penser»), «я вам покорно благодарствую» (ср. «je vous suis bien obligé»), «то бы я вам болшой поклон за то зделал и вас бы благодарить стал» (ср. «je vous ferais un grand compliment pour vous remercier»), «благодарна... за... незабвение» (cp. «remercia... de ses attentions»), «не могу воздать вам доволнова благодарения за ваше одолжение» (ср. «je ne puis m'acquitter des obligations que je vous ai»).

Опыт Х. Д. относится к первым переводам волшебных сказок о феях на русский язык, в связи с чем обратим внимание на лексику, описывающую волшебство. В ее переводе нет понятия о волшебстве (соответствует enchantement оригинала): принц благодарит Лабель за то, «что она окончала ево нещастие» (ср. «remerciait d'avoir fini son enchantement») ${ }^{1}$. Традиционный зачин сказки «il y avait une fois...» Х. Д. переводит словами «в старину жил...» ${ }^{2}$.

Необычен перевод названия цветка, который просит привезти Красавица, - «une rose». Наряду употреблением форм множественного числа «розы» («ты крадешь мои розы») и формы единственного числа «роза» имеет место равное употребление формы «розен» для передачи множественного числа: «“...принеси мне розен, у нас их здесь нету”. Лабель не старалась об розе» (cp. «“...je vous prie de m'apporter une rose, car il n'en vient point ici”. Ce n'est pas que la Belle se souciât d'une rose»), «сорвал веточку, где несколько было розенов» (ср. «il passait sous un berceau de roses... et cueillit

чтоб зжалиться на мое состояние» (cp. «il n'y avait que vous dans le monde assez bonne pour vous laisser toucher à la bonté de mon caractère»).

${ }^{1} \mathrm{Cp}$. с переводом П.С. Свистунова: принц благодарит Красавицу за то, что она «окончала ево муку, волшебством ему определенную» [16. С. 118]. Другая «сказочная» лексика в переводе Х. Д.: «великая волшебница» (une grande fée), «негодная волшебница» (méchante fée), волшебница ударяет «палочкою» (соответствует baguette оригинала, в переводе Свистунова - «прутик»).

${ }^{2}$ Перевод П.С. Свистунова остался без короткого зачина, сказка начинается словами: «Купец очень богатой имел у себя...» [Там же. С. 82]. 
une branche où il y en avait plusieurs»). Это косвенно указывает на то, что, вероятно, девушка учит также немецкий язык, в котором форма множественного числа для обозначения цветка - «Rosen» (именно с немецкого языка начинали свое обучение языкам братья Х. Д.), а также на то, что в домашнем общении в семье Демидовых было принято называть цветок на немецкий манер (напомним, что отец семейства в совершенстве владел немецким).

Во французском оригинале все персонажи обращаются друг к другу на «вы». В переводе Х. Д., напротив, повторяя русскую повседневную практику, персонажи говорят друг другу «ты». За исключением нескольких моментов. Во-первых, переход на вы обозначает этическую высоту межличностных отношений в момент опасности и выбора. Так, намереваясь защищать сестру, братья говорят: «нет, сестрица, вы не умрете». Лабель сообщает о своем решении идти вместо отца к зверю: «Я вас уверяю, батюшка... что вы без меня не пойдете во оной дворец». Во-вторых, когда диалоги Лабель и зверя окрашиваются темой ухаживания, объяснения в любви, предложения руки и сердца. То есть $6 b l$ появляется в ситуации моделирования светского поведения благородной девицы, которое транслирует не его повседневную практику (обращение на «ты»), а новую норму. Проиллюстрируем сказанное.

Отправная точка - Красавица приходит во дворец зверя. Состоялась их первая встреча, здесь еще нет темы ухаживаний: «Лабель не могла удержаться от страху, увидя ужасную образину... звер ее спросил добровольно ли она сюда пришла... “T $T b$ очень справедлива, - сказал ей зверь, - тебе покорно благодарствую, а $m b l,-$ сказал он купцу, - поезжай назадь завтре поутру, и тебе не должно никогда сюда возвращаться. Прости, Лабель”. “Прости, мой зверь" - отвечала она».

Следующим вечером зверь посещает Красавицу за ужином. Перед нами образчик разговора между девицей и молодым человеком с намерениями:

«Лабель, - сказал ей зверь, - не противно ли вам будет, чтоб я на вас смотрел, как вы ужинать станете?» «Tы здесь господин», - отвечала Лабель, трепечущи. «Нет, - говорил зверь, - нет здесь иной хозяйки кроме вac. Bbl только скажите, ежели я вам противен, то я тот же час оттойду прочь. Скажи мне, не скареден ли я?» - «Ето правда, сказала Лабель, ...но я думаю, что ты очень добр». - «Bbl правду говорите, - сказал зверь, - но, сверх того, что я скареден, я не имею разума: я ничего не знаю, как только что я зверь... Кушайте, Лабель, - сказал ей зверь, - и старайтесь, чтоб вам не скушно было в вамем доме, ибо все сие принадлежить вам; и мне очень досадно будет, ежели $в b$ не довольны будете». «Bbl очень милостивы, - сказала Лабель. - Я вам признаюсь, что я довольна вашим благодеянием; и я думаю, то уже вы мне не так скаредны кажетесь...» «Ежели б я имел разум, - сказал зверь, - то бы я вам болшой поклон за то зделал и вас бы благодарить стал, но я глуп; вот все, что я вам могу сказать, я вам покорно благодарствую... Лабель, хотите ли вы быть моею женою?» Она долго ему не отвечала, бояся, чтоб не привесть ево в сердце 
отказом, однако ж сказала ему трепещущи: «Нет, зверь»... зверь, ей печально сказавши «прости же Лабель», вышел из горницы вон».

Bсе другие беседы Лабель и зверя построены по такому же принципу переключения диалога с повседневного общения на «ты» в ухаживание и сватовство, маркированные обращением на «вы».

Для перевода Х. Д. характерно смягчение выражений оригинала с физической семантикой: в деревне Красавица много трудится, потом «она несколько привыкла» (ср. со словами оригинала о том, что она стала сильнеe - «elle devint plus forte»); во дворце зверя уставший и голодный купец «увидел разложенной огонь и стол с кушеньем» (в оригинале на столе в изобилии находятся мясные блюда - «il trouva un bon feu et une table charge de viande»), затем голодный купец «взял цыплионка, которова он с трепетом сьел» (в оригинале купец трепеща съедает цыпленка в два приема «en deux bouchées et en tremblant»).

Итак, выполненный Х.Г. Демидовой перевод сказки Лепренс де Бомон о красавице и чудовище представляет собой ученическую работу, результат которой был поднесен старшему брату в виде подарочно оформленной рукописной книги «Повесть о Лабеле и звере». Для языка перевода характерны синтаксические кальки и в то же время живые русские разговорные выражения. Последнее придало сказочному изложению яркую окраску «русскости» ${ }^{1}$. Именно эта черта роднит демидовский перевод и сказку С.Т. Аксакова «Аленький цветочек», сюжетную основу которой, как известно, составила сказка Лепренс де Бомон «Красавица и зверь» ${ }^{2}$. Между тем язык оригинальной сказки нейтрален и стилистически прост, поскольку свое сочинение Лепренс де Бомон предназначала детям, более того благородным барышням, для которых французский язык был языком обучения, но не был родным [7. Р. 198].

По-видимому, желание связать «Повесть о Лабеле и звере» с «Аленьким цветочком» не только источником, но и возможным влиянием раннего перевода на аксаковскую сказку побудило некоторых исследователей предполагать распространение перевода Демидовой в виде многочисленных списков [17. С. 181; 21. С. 40] $]^{3}$. Напротив, следует признать, что руко-

${ }^{1}$ Перевод П.С. Свистунова, более гладкий и литературный, сохраняет нейтральную лексику оригинала и стилистическую простоту.

${ }^{2}$ Анализ источников сказки С.Т. Аксакова, в том числе сказки Лепренс де Бомон, сопоставление литературных и фольклорных вариантов сказок о красавице и звере см.: [17-20].

${ }^{3}$ Возможно, ошибка, допущенная Ю.К. Бегуновым и затем повторенная многими исследователями, связана с неверным отождествлением «Гистории о французском купце и о дочери ево имянуемой Красавицею», хранящейся в Санкт-Петербургской университетской библиотеке, со списком, якобы сделанным с «Повести о Лабеле и звере». Дело в том, что сведения об этой гистории были сообщены А.Н. Пыпину обладателем «Повести о Лабеле и звере» И.А. Шляпкиным, он же указал на сходство гистории с «Аленьким цветочком» [22. С. 62-63]. Между тем цитированные Пыпиным начало и конец гистории говорят о том, что рукопись восходит к печатному переводу Свистунова, то же показало и знакомство с рукописью de viso [23]. 
писное распространение сказок из сборника Лепренс де Бомон было суждено спискам, сделанным с печатного издания «Детского училища» ${ }^{1}$.

Тем не менее, рукописная книга Хионии Демидовой «Повесть о Лабеле и звере» (ОРКР НЗБ СГУ, № 456) достойна внимания и как первый перевод на русский язык популярной сказки М. Лепренс де Бомон «Красавица и зверь», и как источник наших реконструкций относительно семьи Демидовых, и как материал к изучению языка переводов с французского середины XVIII в. ${ }^{2}$

\section{Лumepamypa}

1. De Beaumont, M. Leprince Magasin des enfants, ou Dialogues entre une sage gouvernante et plusieurs de ses élèves de la première distinction dans lesquels gens... on s'applique autant à leur former le coeur, qu'à leur éclairer l'esprit... Londres, 1756, se vende chez J. Haberkorn et chez les Libraires de cette Ville, t. 1-4.

2. Latapie $S$. Un dispositive intégré: le conte dans le Magasin des enfants de Mme Leprince de Beaumont // Féerie. 2003. № 1. P. 125-144.

3. Привалова Е.П. А.Т. Болотов и театр для детей // XVIII век. Сб. 3. М. ; Л., 1958. C. $242-261$.

4. Лазарчук Р.М. А.Т. Болотов // Словарь русских писателей XVIII века. Л., 1988. Вып. 1: (А-И). С. 114-117.

5. Костюхина M.C. Золотое зеркало: Русская литература для детей XVIII-XIX веков. М. : ОГИ, 2008. 224 с.

6. Павлович C.Э. Пути развития русской сентиментальной прозы XVIII века / под ред. В.А. Западова. Саратов, 1974. 224 с.

7. Stewart J.H. Les vieilles fees ou un «Bizarre assortiment» // Dix-huitieme siècle. 2004. № 36. P. 197-209.

${ }^{1}$ В рукописном виде встречаются полные списки с «Детского училища», но чаще сказки, представленные в разных вариантах полноты состава из сочинения Лепренс де Бомон, вплоть до списков с отдельных сказок. А.Н. Пыпин, говоря о происхождении гистории о французском купце и его дочери Красавице, пишет о том, что источник сказки, без сомнения, французский и восходит к произведениям, указанным самим Аксаковым, но в отношении происхождения других сказок, в частности сказки о принце Любиме и сказки о принце Милобразе, Пыпиным не были сделаны какие-либо предположения [22. С. $63,37,40-41,71-72]$. Впервые популярная в рукописях сказка о принце Любиме была определена как список со сказки с одноименным названием из «Детского училища» Лепренс де Бомон в переводе П.С. Свистунова В.Д. Раком (см.: [24. С. 10]). Независимо от петербургского исследователя О.Н. Фокина на материале пяти сказок из коллекции М.Н. Тихомирова (ОРКиР ГПНТБ СО РАН) пришла к выводу, что списки сделаны с первого русского издания Лепренс де Бомон [25. С. 196]. Во всех известных мне списках (перечень их установлен благодаря картотеке Н.К. Никольского (БАН), работам А.Н. Пыпина и М.Н. Сперанского [26. С. 160-161]) сказка называется «Красавица и зверь», а не «Повесть о Лабеле и звере»; выборочная сверка текстов подтвердила происхождение списков от печатного издания (например, [27, 28]).

${ }^{2}$ Впервые описание рукописи было сделано В.Н. Перетцем в 1934 г. [29. С. 373]. В ходе работы Международного научного семинара «Русско-сибирская франкофония» (Томск, 2015 г.) в числе прочих вопросов были рассмотрены влияние французской литературы на риторику любовного поведения и явление русского аристократического билингвизма; проблематика и выводы исследователей могут быть распространены на представленный в нашей статье материал: [30]. 
8. Villeneuve G.-S. La Jeune Américaine et les contes marins (La Belle et la Bête). Les Belles solitaires. Leprince de Beaumont J.-M. Magasin des enfants (La Belle et la Bête) / Ed. Él. Biancardi. Paris : H. Champion, 2008. 1636 p. (Bibliothèque des Génies et des Fées).

9. Заборов П.Р. П.С. Свистунов // Словарь русских писателей XVIII века. СПб., 2010. Вып. 3: (Р-Я). С. 101-103.

10. Копанев Н.А. Петербургские подписчики на первое лондонское издание «Маgasin des enfants» М. Лепренс де Бомон // Solanus. International journal for Russian at East European Bibliographic, Library and Publishing Studies. New Series. 2015. Vol. 19. P. 84 91.

11. Краснова Е.И. Такие разные Демидовы. СПб., 2007. 152 с. URL: http://www.peter-gen.com/showpages.php?page=007\&pp=4 (дата обращения: 21.04.2018).

12. Марченко E.B. Стахиевы-Демидовы и судьба Крыма // Культурно-историческое наследие как фактор устойчивого развития территории : материалы Всерос. науч.практ. конф. с междунар. участием. Соликамск, 2015. С. 27-30.

13. Санктпетербургский календарь на лето... 1763. СПб., 1762. URL: http://primo.nlr.ru/primo_library/libweb/action/display.do?tabs $=$ detailsTab\&ct $=$ display $\& \mathrm{fn}=\mathrm{s}$ earch\&doc $=07$ NLR LMS009685086\&indx $=1 \&$ recIds $=07$ NLR LMS009685086\&recIdxs $=0$ \&elementId $=0 \&$ renderMode $=$ poppedOut $\&$ displayMode $=$ full $\& \overline{\text { frbrVersion }}=\&$ frbg $=\& \& d s c n t=$ 0\&scp.. scps $=$ scope $\% 3 \mathrm{~A} \% 2807$ NLR $\% 29 \&$ mode=Basic\&vid=07NLR VU1\&srt=rank\&tab=de fault_tab\&vl(freeText0)=38.34.3.38\&dum=true\&dstmp=1524204192194 (дата обращения: 21.04.2018).

14. Победимова Г.А. «К великой пользе России...»: (Образовательное путешествие молодых дворян Демидовых по Европе в 1751-1761 гг.) // Путешествие братьев Демидовых по Европе: Письма и подневные Журналы. 1750-1761 гг. М. : Индрик, 2006. C. $7-50$.

15. Путешествие братьев Демидовых по Европе: Письма и подневные Журналы. 1750-1761 гг. М. : Индрик, 2006. 512 с.

16. Лепренс де Бомон М. Сказка о красавице и звере // Лепренс де Бомон М. Детское училище, или Нравоучительные разговоры между разумною учительницею и знатными разных лет ученицами / пер. П. Свистунова. СПб., 1761. Т. 1. С. 82-120.

17. Бегунов Ю.К. Источники сказки С.Т. Аксакова «Аленький цветочек» // Русская литература. 1983. № 1. С. 179-187.

18. Гистер М.А. Проблема ключницы Пелагеи: сюжет о красавице и звере и сказка С.Т. Аксакова «Аленький цветочек» // Слово устное и слово книжное. М., 2009. С. $374-$ 407.

19. Гистер M.A. Табу vs предписание в фольклорных и литературных сказках о красавице и звере // Миф в фольклорных традициях и культуре Новейшего времени. М., 2009. C. 71-89.

20. Полосина А.Н. Восприятие творчества Лепренс де Бомон в русской литературе XIX века: С.Т. Аксаков и Л.Н. Толстой // Сюжетология и сюжетография. 2014. № 2. C. $115-122$. $208 \mathrm{c}$.

21. Пирогова Е.П. Библиотеки Демидовых: книги и судьбы. Екатеринбург, 2000.

22. Пьиин А.Н. Для любителей книжной старины: Библиографический список рукописных романов, повестей, сказок, поэм и пр., в особенности из первой половины XVIII века. М., 1888. 74 с.

23. РК НБ СПбГУ, MsEII 16. Гистория о француском купце и о дочери ево имянуемой Красавицей, как за ея добродетель избавлен принц из мерскаго чюдовища в человека. Л. 23-42.

24. Рак В.Д. Русские литературные сборники и периодические издания второй половины XVIII века: (Иностранные источники, состав, техника, компиляция). СПб., 1998. $336 \mathrm{c}$. 
25. Фокина О.Н. Рукописи сказок Лепренс де Бомон из собрания М.Н. Тихомирова // Вестник Новосибирского государственного университета. Сер.: История, филология. 2011. Т. 10, вып. 8: Филология. С. 195-215.

26. Сперанский M.H. Рукописные сборники XVIII века: Материалы для истории русской литературы XVIII века. М., 1963. 267 с.

27. ОР ГИМ. Муз. 3081. Сборник. Л. 59-69 об. (Красавица и зверь: сказка).

28. ОР ГИМ. Муз. 2393. Сборник сказок. Л. 243-267 об. (Сказка. Красавица и зверь).

29. Перети В.Н. Описание собрания рукописей проф. И.А. Шляпкина, принесенного в дар владельцем Саратовскому государственному университету (часть первая) // Археографический ежегодник за 1959 г. М., 1960. С. 361-466.

30. Поплавская И.А., Родченко Ю.И., Рудикова Н.А. Международный научный семинар «Русско-сибирская франкофония» (Томск, 11-15 июня 2015 г.) // Сибирский филологический журнал. 2016. № 2. С. 266-273.

\section{THE FIRST RUSSIAN TRANSLATION OF JEANNE-MARIE LEPRINCE DE BEAUMONT'S FAIRY TALE "BEAUTY AND THE BEAST"}

Vestnik Tomskogo gosudarstvennogo universiteta. Filologiya - Tomsk State University Journal of Philology. 2018. 56. 248-262. DOI: 10.17223/19986645/56/13

Lyubov A. Kurysheva, Institute of Philology of the Siberian Branch of the Russian Academy of Sciences (Novosibirsk, Russian Federation). E-mail: kurysh@mail.ru

Keywords: Russian literature of 18th century, handwritten fiction, Demidov family, J.-M. Leprince de Beaumont, "Beauty and the Beast", folktale type AT 425 C.

The study of Khioniya Demidova's translation of the fairy tale "Beauty and the Beast" (Saratov, Shlyapkin Collection, No. 456) gives an idea of the Russian-French lexicon of the mid-18th century, of the practice of teaching foreign languages in Russian noble families in the mid-18th century, and complements our notions of relations in the Demidov family. The translation of the tale was made by young Demidova in 1758, two years after the publication of Leprince de Beaumont's Magasin des enfants (Vols 1-4, Londres, 1756).

The French-language textbook by Leprince de Beaumont Magasin des enfants contained instructive conversations, initial information on geography, history, extracts from the Holy Scripture and moralizing tales; among the latter was a fairy tale about a beauty and a beast, whose fame surpassed its direct source, the novel Histoire de la Belle et de la Bête (1740) by Gabrielle-Suzanne Barbot de Villeneuve.

Apparently, Demidova received this book among other new books that her older brothers sent regularly from their educational tour of Europe in 1750-1761. The brothers could learn the news about the publication of the original textbook intended for the upbringing and education of noble young ladies in their "Russian" foreign circle. During the trip, the Demidovs regularly communicated with representatives of the Russian aristocracy and diplomats close to the court, including A.M. Golitsyn, M. Posse, A.S. Stroganov, K.E. Sivers. All these persons were among the Russian subscribers of the London edition of Leprince de Beaumont.

The hand-written book created by Demidova looks like a gift and is dedicated to her brother, Pyotr Grigorievich Demidov.

Demidova's translation as a whole accurately follows the original, including syntactic calques. Errors in declension and unstable spelling suggest that Khioniya was learning the Russian written language simultaneously with French, and that her Russian writing was phonetic rather than conventional, reinforced by the knowledge of the Russian grammar. A striking feature of the translation is the use of colloquial expressions and a regular use of Russian realities. This gave the fairy tale traits of "Russianness", which is especially noticeable against the background of the neutral stylistics of the printed translation (by Pyotr Svistunov) of $M a$ gasin des enfants published in 1761. 
Some researchers mistakenly believe that Demidova's handwritten translation was distributed in the form of numerous manuscripts. On the contrary, it must be admitted that it was the printed edition that was distributed in a handwritten form. Nevertheless, Khioniya Demidova's translation deserves attention as the first translation into Russian of the popular fairy tale "Beauty and the Beast" in the "Russian" style (S.T. Aksakov's version continued this direction).

"Povest' o Labelle i zvere" [A Tale of Beauty and the Beast] (Saratov University Library, No. 456) is published for the first time.

\section{References}

1. Leprince De Beaumont, J.-M. (1756) Magasin des enfants, ou Dialogues entre une sage gouvernante et plusieurs de ses élèves de la première distinction dans lesquels gens... on s'applique autant à leur former le coeur, qu'à leur éclairer l'esprit... [Magazine for children, or Dialogues between a wise governess and several pupils of the first distinction, in which the young people are made to think, speak and act according to the genius, temperament and inclinations of each ... .]. Vols 1-4. London. Soldat J. Haberkorn and at the booksellers of this city.

2. Latapie, S. (2003) Un dispositive intégré: le conte dans le Magasin des enfants de Mme Leprince de Beaumont [An integrated device: the tale in the Magazine for Children of Mrs. Leprince de Beaumont]. Féerie. 1. pp. 125-144.

3. Privalova, E.P. (1958) A.T. Bolotov i teatr dlya detey [A.T. Bolotov and children's theater]. In: Berkov, P.N. (ed.) XVIII vek [The 18th century]. Coll. 3. Moscow; Leningrad: USSR AS.

4.Lazarchuk, R.M. (1988) A.T. Bolotov. In: Slovar' russkikh pisateley XVIII veka [Dictionary of Russian writers of the 18th century]. Is. 1. Leningrad: Nauka.

5. Kostyukhina, M.S. (2008) Zolotoe zerkalo: Russkaya literatura dlya detey XVIII-XIX vekov [Golden mirror: Russian literature for children of the 18th -19 th centuries]. Moscow: OGI.

6. Pavlovich, S.E. (1974) Puti razvitiya russkoy sentimental'noy prozy XVIII veka [Ways of development of Russian sentimental prose of the 18th century]. Saratov: Saratov State University.

7. Stewart, J.H. (2004) Les vieilles fees ou un "Bizarre assortiment" [Old Fees or a "Bizarre Assortment"]. Dix-huitieme siècle. 36. pp. 197-209.

8. Villeneuve, G.-S. (2008) La Jeune Américaine et les contes marins (La Belle et la Bête). Les Belles solitaires. Leprince de Beaumont J.-M. Magasin des enfants (La Belle et la Bête) [The American Girl and Sea Tales (Beauty and the Beast). The Lonely Beauties. Leprince de Beaumont J.-M. Magazine for Children (Beauty and the Beast)]. Paris: H. Champion.

9. Zaborov, P.R. (2010) P.S. Svistunov. In: Panchenko, A.M. (ed.) Slovar' russkikh pisateley XVIII veka [Dictionary of Russian writers of the 18th century]. Is. 3. St. Petersburg: Nauka.

10. Kopanev, N.A. (2015) Peterburgskie podpischiki na pervoe londonskoe izdanie "Magasin des enfants" M. Leprens de Bomon [Petersburg subscribers to the first London edition of "Magasin des enfants" by J.-M. Leprince de Beaumont]. Solanus. International Journal for Russian at East EuropeanBibliographic, Library and Publishing Studies. New Series. 19. pp. 84-91.

11. Krasnova, E.I. (2007) Takie raznye Demidovy [The Demidovs: So different]. St. Petersburg: SPBGUTD.

12. Marchenko, E.V. (2015) [The Stakhievs-Demidovs and the fate of the Crimea]. Kul turno-istoricheskoe nasledie kak faktor ustoychivogo razvitiya territorii [Cultural and historical heritage as a factor in the sustainable development of the territory]. Proceedings of the International Conference. Solikamsk: Solikamsk State Pedagogical University. pp. 27-30. (In Russian). 
13. Rumovskiy, S.Ya. (1762) Sanktpeterburgskiy kalendar' na leto... 1763 [St. Petersburg calendar for the summer of 1763]. [Online] Available from: http://primo.nlr.ru/primo_library/libweb/action/display.do?tabs $=$ detailsTab\&ct $=$ display $\& \mathrm{fn}=\mathrm{se}$ arch\&doc $=07$ NLR_LMS009685086\&ind $=1 \&$ recIds $=07$ NLR_LMS009685086\&recIdxs $=0 \&$ elemen-

tId $=0 \&$ renderMode $=$ poppedOut $\&$ displayMode $=$ full $\&$ frbrVersion $=\&$ frbg $=\& \&$ dscnt $=0 \&$ scp.sc ps $=$ scope $\% 3 \mathrm{~A} \% 2807 \mathrm{NLR} \% 29 \&$ mode $=$ Basic\&vid=07NLR_VU1\&srt=rank\&tab=default_tab $\& v 1($ freeText0) $=38.34 .3 .38 \& d u m=$ true $\& d s t m p=1524204192194$. (Accessed: 21.04 .2018$)$.

14. Pobedimova, G.A. (2006) Puteshestvie brat'ev Demidovykh po Evrope: Pis'ma i podnevnye Zhurnaly. 1750-1761 gg. [Journey of the Demidov brothers in Europe: Letters and Daily Journals. 1750-1761]. Moscow: Indrik. pp. 7-50.

15. Pobedimova, G.A. (2006) Puteshestvie brat'ev Demidovykh po Evrope: Pis'ma i podnevnye Zhurnaly. 1750-1761 gg. [Journey of the Demidov brothers in Europe: Letters and Daily Journals. 1750-1761]. Moscow: Indrik.

16. Leprince de Beaumont, J.-M. (1761) Detskoe uchilishche, ili Nravouchitel'nye razgovory mezhdu razumnoyu uchitel'nitseyu i znatnymi raznykh let uchenitsami [Magazine for children, or Dialogues between a wise governess and several pupils of the first distinction, in which the young people are made to think, speak and act according to the genius, temperament and inclinations of each ... .]. Translated from French by P. Svistunov. Vol. 1. St. Petersburg: tip. Svhoputn. kad. korpusa. pp. 82-120.

17. Begunov, Yu.K. (1983) Istochniki skazki S. T. Aksakova "Alen'kiy tsvetochek" [Sources of S.T. Aksakov's fairy tale "The Scarlet Flower"]. Russkaya literatura. 1. pp. 179-187.

18. Gister, M.A. (2009) Problema klyuchnitsy Pelagei: syuzhet o krasavitse i zvere i skazka S.T. Aksakova "Alen'kiy tsvetochek" [The problem of Pelageya, the key holder: the story of the beauty and the beast and S.T. Aksakov's fairy tale "The Scarlet Flower"]. In: Gister, M.A. (ed.) Slovo ustnoe i slovo knizhnoe [Word of mouth and word of book]. Moscow: RSUH.

19. Gister, M.A. (2009) Tabu vs predpisanie v fol'klornykh i literaturnykh skazkakh o krasavitse i zvere [Taboo vs prescription in folklore and literary tales about beauty and the beast]. In: Neklyudov, S.Yu. (ed.) Mif $v$ fol'klornykh traditsiyakh i kul'ture Noveyshego vremeni [Myth in the folklore traditions and culture of the Modern Time]. Moscow: RSUH.

20. Polosina, A.N. (2014) The perception of works of Leprince De Beaumont in Russian literature of XIX century: S.T. Aksakov and L.N. Tolsoy. Syuzhetologiya i syuzhetografiya. 2. pp. 115-122. (In Russian).

21. Pirogova, E.P. (2000) Biblioteki Demidovykh: knigi i sud'by [Libraries of the Demidovs: books and destinies]. Yekaterinburg: Sokrat.

22. Pypin, A.N. (1888) Dlya lyubiteley knizhnoy stariny. Bibliograficheskiy spisok rukopisnykh romanov, povestey, skazok, poem i pr., v osobennosti iz pervoy poloviny XVIII veka [For lovers of book antiquity. Bibliographic list of handwritten novels, novellas, fairy tales, poems, etc., especially from the first half of the 18th century]. Moscow Tipo-lit. I.N. Kushnereva i K.

23. Rare Books Department of St. Petersburg State University Research Library. MsEII 16. Gistoriya o frantsuskom kuptse i o docheri evo im yanuemoy Krasavitsey, kak za eya dobrodetel' izbavlen prints iz merskago chyudovishcha $v$ cheloveka [The story of a French merchant and his daughter he called Belle, as for her virtue, the prince was freed from an ugly beast into a man]. pp. 23-42.

24. Rak, V.D. (1998) Russkie literaturnye sborniki i periodicheskie izdaniya vtoroy poloviny XVIII veka: (Inostrannye istochniki, sostav, tekhnika, kompilyatsiya) [Russian literary collections and periodicals of the second half of the 18th century: (Foreign sources, composition, technique, compilation)]. St. Petersburg: Akademicheskiy proekt.

25. Fokina, O.N. (2011) Tales of Leprince de Beaumont in the manuscripts from M.N. Tikhomirov's collection. Vestnik Novosibirskogo gosudarstvennogo universiteta. Ser.: 
Istoriya, filologiya - Vestnik Novosibirsk State University. Series: History and Philology. 10 (8). pp. 195-215. (In Russian).

26. Speranskiy, M.N. (1963) Rukopisnye sborniki XVIII veka: Materialy dlya istorii russkoy literatury XVIII veka [Manuscript collections of the 18th century: Materials for the history of Russian literature of the 18th century]. Moscow: USSR AS.

27. Manuscript Department of the State Historical Museum of Russia (OR GIM). Muz. 3081. Sbornik [Collection]. pp. 59-69 rev. (Krasavitsa i zver': skazka [Beauty and the beast: a fairy tale]).

28. Manuscript Department of the State Historical Museum of Russia (OR GIM). Muz. 2393. Sbornik skazok [Collection of fairy tales]. pp. 243-267 rev. (Skazka. Krasavitsa i zver' [A fairy tale. Beauty and the beast]).

29. Peretts, V.N. (1960) Opisanie sobraniya rukopisey prof. I.A. Shlyapkina, prinesennogo $\mathrm{v}$ dar vladel'tsem Saratovskomu gosudarstvennomu universitetu (chast' pervaya) [Description of the collection of manuscripts of Prof. I.A. Shlyapkin, donated by the owner to Saratov State University (Part One)]. In: Tikhomirov, M.N. (ed.) Arkheograficheskiy ezhegodnik za $1959 \mathrm{~g}$. [Archeographic Yearbook for 1959]. Moscow: Nauka.

30. Poplavskaya, I.A., Rodchenko, Yu.I. \& Rudikova, N.A. (2016) International Scientific Seminar "Russian-Siberian Francophonie" (Tomsk, 11-15 June, 2015). Sibirskiy filologicheskiy zhurnal - Siberian Journal of Philology. 2. pp. 266-273. (In Russian). DOI: $10.17223 / 18137083 / 55 / 28$ 